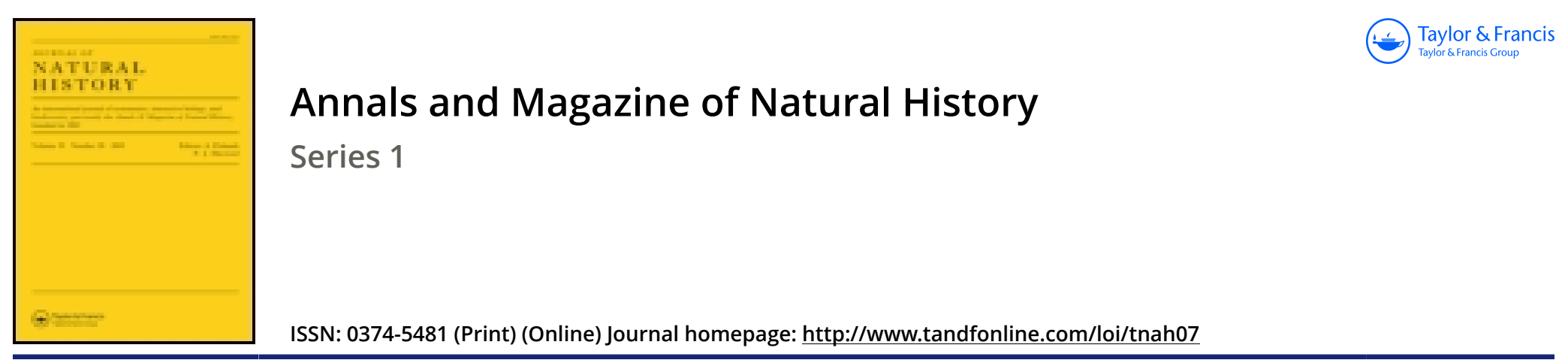

\title{
Lestris parasiticus
}

\section{J. Hancock}

To cite this article: J. Hancock (1838) Lestris parasiticus, Annals and Magazine of Natural History, 2:8, 159-159, DOI: 10.1080/00222933809512359

To link to this article: http://dx.doi.org/10.1080/00222933809512359

曲 Published online: 15 Mar 2010.

Submit your article to this journal 중

Q View related articles $\longleftarrow$ 
LESTRIS TARASITICUS.

A mature individual of the Lestris parasiticus, Tem., was shot near Whitburn in the county of Durham, about the 24th Oct. 1837, and is now in my possession.-J. Hancock.

\section{OCCÜRRENCE OF COPPER IN PLANTS.}

M. Wiegmann, senr., has lately announced that Prof. Sprengel of Brunswick had found in the cinders of Trifolitm pratense 3 per cent. of copper, and that he had also found the same quantity of this metal in those of Trifolium pannonicum, cultivated in his garden, the soil of which is very different from that whence the Trif. pratense had been obtained. M. Sprengel subsequently examined some trefoils grown in a field, the soil of which did not indicate any traces of this metal in its composition; and was convinced that its existence in the two former was owing to its presence in the ground where the plants were cultivated. The fact affirmed by M. Sprengel proves that a small quantity of a noxious substance may be absorbed by plants without any prejudice to their development.Flora.

\section{OCCURRENCE OF FALCO ISLANDICUS IN ENGLAND.}

A specimen of the Iceland Falcon (Falco Islandicus) in first plumage was shot at Normanby, Yorkshire, March 1837; and another individual in the Newcastle Museum, which is a female and in the mature plumage, was shot in Northumberland a few years ago. These two instances are sufficient to rank the Iceland species as a British bird.-J. HaNcook.

METEOROLOGICAL OBSERVATIONS FOK AUGUST 1838.

Chisurck,-August 1. Very fine: heavy rain at tight. 9. Rain. 3. Fine. 4. Overcast: slight rain. 5. Cloudy, 6. Sultry, with showers. 7. Showery. 8, 9. Fine. 10. Overcast. $11-16$. Very fine. 17. Ilazy : slight rain, $18-20$. Very fine. 21. Showery. 22. Rain. 23. Showery. 24. Cloudy and fine. 25. Foggy : rain. 26, 27. Very fine. 28. Overcast: lightning at night. 29. Cloudy and fine, 30. Clear and dry. 31. Very fine.

Roston.-August 1. Fine. 2. Cloudy : rain early A.M. 3. Rain. 4. Fine : rain r. M. 5. Fine. 6. Cloudy: raill p.a. 7. Heavy rain with thunder and lightning P.M. 8. Cloudy. 9. Fine : rain P.x. 10. Cloudy: rain P.M. 11, 12. Cloudy. 13 $\rightarrow$ 15. Fine. 16. Cloudy. 17, 18. Fine. 19, 20. Windy. 21.

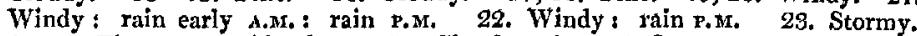
24, 25. Fine. 26. Cloudy. 27. Cloudy: therm. $74^{\circ} 6$ p.ur. 28. Cloudy. 29. Windy : rain early A.M. 30, 31 . Fine.

Applegarth Manse, Dumfries-shire.-August 1. Rain P.sr.: warm and moist. 2. Fine day throughout. 3. Fine day : occasional showers. 4. Moist and cloudy. 5. Heavy rain ..M. 6. Very heavy showers. 7. Showery all day. 8. Fine summer day : cool P.M, 9. Wet throughout. 10. Fair A.M. : wet evening. 11. Drizzling rain $A_{1} M_{*}:$ fair P.M. 12. Fair: shower P.M. 13. Fair: shower at noon. 14. Fair throughout. 15. Fine clear day, 16. Temperate : cool. 17. Beautiful summer day. 18. Cloudy ; noist P.x. 19, 20. Showery all day. 21. Rainy all day : flood. 22. Showery all day. 23, 24. Fair A.nr.: shower P.s.: 25. Very moist : rain P.M. 26. Fair : warm : cloudy. 27. Fair, but threatening. 28, Drizzling all day. 29. Clear and cool, 30 .

Temperate. 31. Mild though cloudy. 